\title{
Effect of the membrane/protein interaction nature on adsorptive properties of ultrafiltration membranes based on aromatic poly- and copolyamides
}

\author{
Smirnova N.N., Nebukina I.A. \\ Vladimir State University named after A.G. and N.G. Stoletovs, Vladimir \\ Поступила в редакцию 28.12.2017 г.
}

DOI: https://doi.org/10.17308/sorpchrom.2018.18/539

Membranes are a science intensive product of interindustry use, without which a breakthrough development of basic and high-technology sectors of economy, development of science as well as effective solution of important goals of the social sphere and problems of environment protections are impossible. Active development of medicine, pharmaceutical industry and biotechnology in the recent years contributed to the growth of scientific and commercial interest in ultrafiltration. The most important characteristic of ultrafiltration membranes is selectivity. According to existing views the basis of the separation mechanism implemented in ultrafiltration is size selectivity. However, such phenomena as concentration polarization and adsorption play a very important role in separation. Investigation of these phenomena is of significant practical interest, because its results in many ways determine the choice of the membrane media, conditions of its recovery, the mode and conditions of filtration. Adsorption of proteins on the surface of porous membranes is a rather complicated process due to the individual mechanism implemented in each specific case. Therefore, the issue of the contribution of various types of interactions into the process of adsorption still remains controversial. To determine the nature of membrane/protein interaction and clarify the factors of its control, the present work involved investigation of sorption of several proteins on a number of synthesized porous membranes based on aromatic polyamides noted for the presence, nature and concentration of ionogenic groups. The investigations were carried out using bovine serum albumin, lysozyme of hen's eggs, myoglobin and bacitracin. Adsorption of proteins by the membranes was investigated in the static mode. The protein concentration was determined using the SF-2000 spectrophotometer (experimental-design bureau Spektr) by optical density at the wave length $\lambda=278 \mathrm{~nm}$. To mathematically process the experimental data, the two-parameter models by Langmuir, Freundlich, Temkin and the three-parameter model by Langmuir-Freundlich were used. To assess the compliance degree of the experimental data to the selected mathematical models, the values of the coefficient of determination $\left(\mathrm{R}^{2}\right)$ and sum squares errors (SSE) were used. It has been shown that in the case of the presence of charge in protein macromolecules and the membrane surface the role of electrostatic forces is dominant in the protein adsorption mechanism, however, the contribution of non-electrostatic interactions in the investigated membrane/protein systems is significant.

Keywords: aromatic polyamides, membrane, proteins, adsorption, isotherm models.

\section{Влияние природы взаимодействия мембрана/белок на адсорбционные свойства ультрафильтрационных мембран на основе ароматических поли- и сополиамидов}

\author{
Смирнова Н.Н., Небукина И.А.
}

Владимирский государственный университет им. А. Г. и Н. Г. Столетовых, Владимир

Smirnova et al. / Сорбционные и хроматографические процессы. 2018. Т. 18. № 3 
Мембраны являются наукоемкой продукцией межотраслевого применения, без которой невозможно прорывное развитие базовых и высокотехнологичных секторов экономики, развитие науки, а также эффективное решение важных задач социальной сферы и проблем экологии. Активное развитие в последние годы медицины, фармацевтической промышленности и биотехнологии способствовали росту научного и коммерческого интереса к ультрафильтрации. Важнейшей характеристикой ультрафильтрационных мембран является селективность. Согласно существующим представлениям в основе реализуемого при ультрафильтрации разделительного механизма лежит размерная селективность. Однако очень важную роль в разделении играют такие явления как концентрационная поляризация и адсорбция. Исследование этих явлений представляет значительный практический интерес, т.к. его результаты во многом определяют выбор материала мембраны, условий ее регенерации, режима и условий проведения фильтрации.

Адсорбция белков на поверхности пористых мембран является достаточно сложным процессом в силу индивидуальности реализуемого в каждом конкретном случае механизма. Поэтому вопрос о вкладе в процесс адсорбции различных видов взаимодействий по-прежнему остается дискуссионным. Для определения природы взаимодействия мембрана/белок и выявления факторов его регулирования в настоящей работе проведено исследование сорбции ряда белков на серии синтезированных пористых мембран на основе ароматических полиамидов, отличающихся наличием, природой и концентрацией ионогенных групп. Исследования проводили с использованием бычьего сывороточного альбумина, лизоцима куриных яиц, миоглобина и бацитрацина. Адсорбцию белков мембранами изучали в статическом режиме. Концентрацию белка определяли с помощью спектрофотометра СФ2000 (ОКБ «Спектр») по оптической плотности при длине волны $\lambda=278$ нм. Для математической обработки экспериментальных данных использовали двухпараметрические модели адсорбции Ленгмюра, Фрейндлиха, Темкина и трехпараметрическую модель Ленгмюра - Фрейндлиха. Для оценки степени соответствия экспериментальных данных выбранным математическим моделям использовали значения $\mathrm{R}^{2}$ и SSE. Показано, что при наличии заряда у белковых макромолекул и поверхности мембраны роль электростатических сил является определяющей в механизме адсорбции белка, однако вклад неэлектростатических взаимодействий в изученных системах мембрана/белок значителен.

Ключевые слова: ароматические полиамиды, мембраны, белки, адсорбция, изотермы адсорбции

\section{Introduction}

Membranes are a science intensive product of interindustry use, without which a breakthrough development of basic and high-technology sectors of economy, development of science as well as effective solution of important goals of the social sphere and problems of environment protections are impossible [1,2]. Active development of medicine, pharmaceutical industry and biotechnology in the recent years contributed to the growth of scientific and commercial interest in ultrafiltration. According to expert assessments, the total rate of annual growth of ultrafiltration plants is $5.7 \%$ [3]. The certain advantage of ultrafiltration membranes when used for purification and concentration of biologically active organic compounds, including proteins is the "gentle conditions" of the separation processes. The most important characteristic of ultrafiltration membranes is selectivity. According to existing views, the basis of the separation mechanism implemented in ultrafiltration is size selectivity. However, such phenomena as concentration polarization and adsorption play a very important role in separation [4]. Investigation of these phenomena is of significant practical interest, because its results in many ways determine the choice of the membrane media, conditions of its recovery, the mode and conditions of filtration.

Adsorption of proteins on the surface of porous membranes is a rather complicated process due to the individual mechanism implemented in each specific case. Therefore, the issue of the contribution of various types of interactions into the process of adsorption still remains controversial. The investigations carried out made it possible to establish the interrelationship of adsorption to the nature of the adsorbate, properties of the adsorbent, the conditions of the adsorbate/adsorbate and adsorbate/adsorbent equilibrium, concentration of the adsorbate, the conformational condition of its macromolecules, $\mathrm{pH}$ of the solution 
and its ionic force as well as operational parameters of the filtration process (transmembrane pressure, the way of supply of the solution being filtered, etc) [5-13].

To determine the effect of membranes electrosurface properties on their adsorption characteristics, the present work involved investigation of adsorption of several proteins on a number of synthesized porous membranes based on aromatic polyamides noted for the presence, nature and concentration of ionogenic groups. The choice of polyamides as the membrane forming media was due to wide-known advantages of this class of polymers, such as their increased mechanical strength, high heat stability, good stability to chemical and thermal-oxidative degradation, which in combination with high transport and separation characteristics determines their active use in production of polymer membranes [14, $15]$.

\section{Materials and methods}

Membranes. Samples of wet-spun ultrafiltration membranes made by the phase inversion method based on poly-m-phenyleneisophthalamide (PA), a functionalized copolyamide of the following structure (OAO Polymersintez):

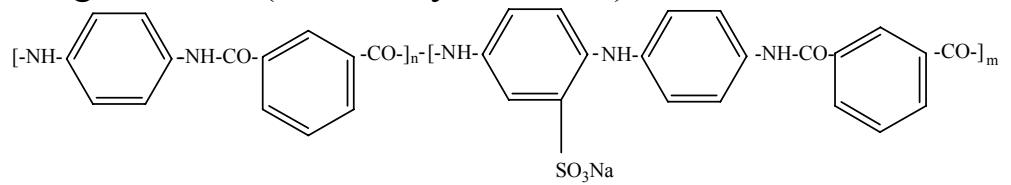

$\mathrm{n}=99, \mathrm{~m}=1 \mathrm{~mol} . \%(\mathrm{PA}-1(-))$

$\mathrm{n}=97, \mathrm{~m}=3 \mathrm{~mol} . \%(\mathrm{PA}-3(-))$

$\mathrm{n}=95, \mathrm{~m}=5 \mathrm{~mol} . \%(\mathrm{PA}-5(-))$

$\mathrm{n}=90, \quad \mathrm{~m}=10 \mathrm{~mol} . \%(\mathrm{PA}-10(-))$

and a mixture of poly-m-phenyleneisophthalamide, containing 10 weight $\%$ of the acrylonitrile/dimethyldiallyl ammoniumchloride copolymer (OAO Kaustik) (PA-10(+)) were used in the work.

The rated cut off molecular weight of the investigated samples was 30 to $50 \mathrm{kDa}$ [16]. The results of investigations of their electric surface properties [17] are presented in Table 1.

Table 1. Electrosurface properties of polyamide membranes

\begin{tabular}{|c|c|c|c|c|c|c|}
\hline Membrane & PA & PA-1(-) & PA-3(-) & PA-5(-) & PA-10(-) & PA-10(+) \\
\hline $\begin{array}{c}\zeta \text {-potential, } \\
\text { mV }\end{array}$ & +2.4 & -5.3 & -14.7 & -25.5 & -43.8 & +9.5 \\
\hline
\end{tabular}

Proteins. The investigations were carried out using bovine serum albumin (BSA) (Sigma), lysozyme of hen's eggs (Lys) (AppliChem), myoglobin (Myo) (Sigma) and bacitracin (Baci) (Sigma). Characteristics of the proteins are presented in Table 2.

Table 2. Characteristics of proteins

\begin{tabular}{|c|c|c|c|c|}
\hline Protein & $\begin{array}{c}\text { Molecular } \\
\text { weight, } \mathrm{kDa}\end{array}$ & $\mathrm{pI}$ & $\begin{array}{c}\text { Stokes radius of } \\
\text { the molecule } \\
r_{\mathrm{s}}, \AA\end{array}$ & Structure \\
\hline 1 & 2 & 3 & 4 & 5 \\
\hline $\begin{array}{l}\text { Bovine serum } \\
\text { albumin } \\
{[18-20]}\end{array}$ & 67.0 & 4.9 & 34.0 & $\begin{array}{c}\text { Ala - 48; Phe - 30; Lys - 60; } \\
\text { Pro - 28; Thr - 34; Cys - 35; } \\
\text { Gly - 17; Leu - 65; Gln - 21; } \\
\text { Val - 38; Asp - 41; His - 16; } \\
\text { Met - 5; Arg - 26; Trp - 2; Glu } \\
\text { - 58; Ile - 15; Asn - 14; Ser - } \\
\text { 32; Tyr - 21 }\end{array}$ \\
\hline
\end{tabular}




\begin{tabular}{|c|c|c|c|c|}
\hline 1 & 2 & 3 & 4 & 5 \\
\hline $\begin{array}{l}\text { Lysozyme } \\
{[21-22,24]}\end{array}$ & 14.3 & 11.0 & 20.6 & $\begin{array}{c}\text { Asp - 7; Glu - 2; His }-1 ; \text { Lys - } \\
6 ; \text { Tyr }-3 ; \text { Arg }-11 ; \alpha \text {-amino - } \\
1 ; \alpha \text {-carboxyl }-1\end{array}$ \\
\hline $\begin{array}{l}\text { Myoglobin } \\
{[19,23,25]}\end{array}$ & 16.8 & 7.0 & 16.0 & $\begin{array}{l}\text { Asp - 8; Glu - 13; His - 7; Lys } \\
-19 ; \text { Tyr }-2 ; \text { Arg }-2 ; \alpha \text {-amino } \\
-1 ; \alpha \text {-carboxyl }-1 ; \text { heme- } \\
\text { carboxyl }-2\end{array}$ \\
\hline $\begin{array}{c}\text { Bacitracin } \\
{[18,19]}\end{array}$ & 1.45 & $7.1-7.2$ & 8.3 & $\begin{array}{c}\text { Cys - 0-5; Arg - } 1 \text {; Lys - } 1 \text {; His - } \\
\text { 1; Asp - } 2 \text {; Glu - } 1 \text {; Phr }-1 \text {; Leu } \\
-1 \text {; iso-Leu }-2\end{array}$ \\
\hline
\end{tabular}

Adsorption experiments. Adsorption of proteins by the membranes was investigated in the static mode. Samples having the area of 1 to $2 \mathrm{~cm}^{2}$ were used for the experiment. The volume of the protein solution was $2.5 \mathrm{~cm}^{3}$. A universal buffer was used to prepare the solutions. Adsorptive properties of the membranes were assessed by the change of protein content in the solutions after maintaining samples in them until the achievement of equilibrium. The protein concentration was determined using the SF-2000 spectrophotometer (experimental-design bureau Spektr) by optical density at the wave length $\lambda=278 \mathrm{~nm}$.

The number of parallel tests in series of experiments was no less than five. The results describing the experimental data were processed using the theory of errors. The confidence interval was calculated to the significance level of 0.05 .

Equilibrium parameters of adsorption. To mathematically process the experimental data, the two-parameter models by Langmuir, Freundlich, Temkin and the three-parameter model by Langmuir-Freundlich were used [26-28] (Table 3).

Table 3. Adsorption isotherms models

\begin{tabular}{|c|c|c|}
\hline Name & Isotherm model & $\begin{array}{c}\text { Description for constants and parame- } \\
\text { ters }\end{array}$ \\
\hline Langmuir isotherm & $Q=\frac{Q_{m} b C}{1+b C}$ & $\begin{array}{c}\mathrm{Q}_{\mathrm{m}}-\text { maximum adsorption calculated } \\
\text { value, } \mathrm{mg} / \mathrm{cm}^{2} ; \mathrm{b}-\text { constant, describ- } \\
\text { ing the affinity in adsorbate/adsorbent } \\
\text { system, } \mathrm{dm} / \mathrm{mg}\end{array}$ \\
\hline Freundlich isotherm & $Q=K_{F} C^{1 / n}$ & $\begin{array}{c}\mathrm{K}_{\mathrm{F}}-\text { constant which represents adsorp- } \\
\left.\text { tion capacity, }\left(\mathrm{dm}^{3}\right)^{1 / \mathrm{n}}(\mathrm{mg})^{1-1 / \mathrm{n}}\right) / \mathrm{cm}^{2} \\
\mathrm{n}-\text { parameter which indicates adsorp- } \\
\text { tion intensity }\end{array}$ \\
\hline Temkin isotherm & $Q=\frac{R T}{b_{T}} \ln A_{T}+\left(\frac{R T}{b_{T}}\right) \ln C$ & $\mathrm{~A}_{\mathrm{T}}-$ constant, $\mathrm{dm}^{3} / \mathrm{g} ; \mathrm{b}_{\mathrm{T}}$ - parameter \\
\hline $\begin{array}{c}\text { Langmuir and Freun- } \\
\text { dlich isotherm }\end{array}$ & $Q=Q_{m} \frac{\left(K_{L F} C\right)^{1 / n}}{1+\left(K_{L F} C\right)^{1 / n}}$ & $\mathrm{~K}_{\mathrm{LF}}-$ constant, $\mathrm{dm}^{3} / \mathrm{mg}$ \\
\hline
\end{tabular}

$\mathrm{Q}$ - equilibrium adsorption capacity of a membrane, $\mathrm{mg} / \mathrm{cm}^{2} ; \mathrm{C}$ - concentration of protein in solution at the moment of equilibrium, $\mathrm{mg} / \mathrm{dm}^{3}$.

Error functions. To assess the compliance degree of the experimental data to the selected mathematical models, the values of the coefficient of determination $\left(\mathrm{R}^{2}\right)$ and sum squares errors (SSE) [27] were used.

Spectral investigations. IR spectra of air-dry samples were taken using the FSM 1202 spectrometer involving Fourier transformation (Monitoring Ltd). 


\section{Results and discussion}

Experimental isotherms of protein adsorption by the synthesized membranes are presented in Fig. 1.
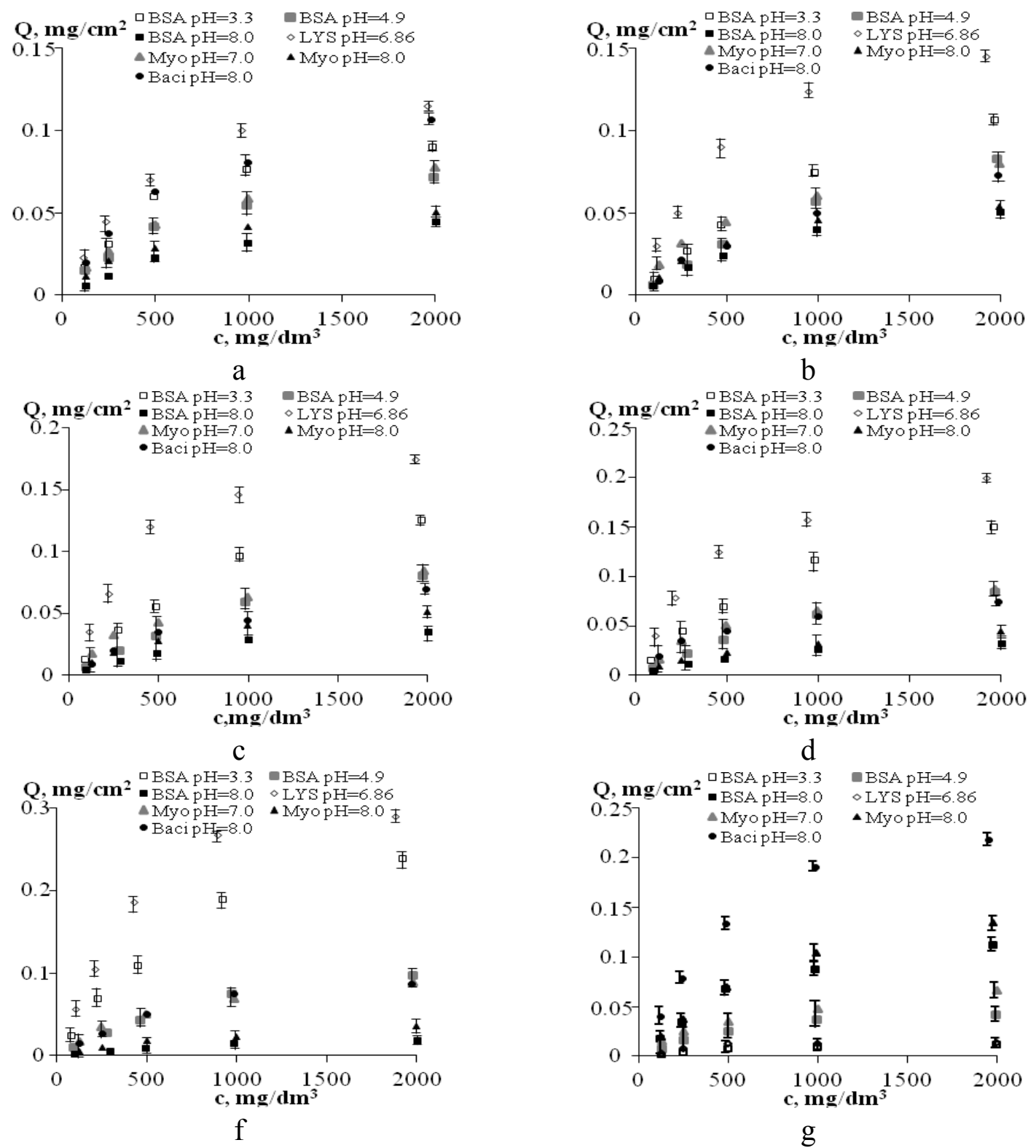

Fig. 1. Experimental isotherms of protein adsorption by membranes

PA (a), PA-1(-) (b), PA-3(-) (c), PA-5(-) (d), PA-10(-) (f), PA-10(+) (g); T=20 ${ }^{\circ} \mathrm{C}$

Considering the adsorption mechanism of proteins by polymer membranes, the authors of the work [29] pointed to the possible implementation of electrostatic, Van der Waals, hydrophobic, hydrophilic, structural and steric interactions. However, the comparative assessment of the contribution of interaction of non-electrostatic and coulomb forces (including both attraction and repulsion) to the total energy of interaction allowed them to make the conclusion on the domination of the latter. Authors of other investigations came to a similar conclusion [30-32]. According to the data presented in work, [33] the contribution to the magnitude of free energy of protein adsorption of coulomb forces is $\sim 10$ to 20 $\mathrm{kJ} /$ mole. The contribution of Van der Waals interactions is $\sim 10 \mathrm{~kJ} / \mathrm{mole}$, that of hydrophobic forces is $\sim 10 \mathrm{~kJ} / \mathrm{mole}$, that of hydrogenic interactions is $\sim 4$ to $9 \mathrm{~kJ} / \mathrm{mole}$. 
The experimental data presented in Fig.1, 2 comply well with basic conclusions on the role of electrostatic forces in the protein adsorption process stated in the works [29-32]. In the case of membranes containing sulfonate groups and having a negative charge of the surface, maximum adsorption is observed at $\mathrm{pH}$ below $\mathrm{pI}$ of the proteins, i.e. in the case their macromolecules are positively charged (Fig.2(b)). A well-defined dependence is seen between the composition of the sulfonate-containing copolyamide and adsorptive capacity of the membrane made from it in the conditions of maximal adsorption (Fig.1(b, c, d, f)).

At $\mathrm{pH}$ equal to $\mathrm{pI}$ of the proteins, adsorption mainly results from non-electrostatic forces. The adsorptive capacity of the membranes based on the sulfonate-containing copolyamide in this area is lower than at $\mathrm{pH}<\mathrm{pI}$. However, the values of $\mathrm{Q}$ of investigated samples obtained in the course of the experiments are rather high (Fig.2(a)). In the case of absence of the charge of the protein macromolecule, the decisive factor becomes not the fact of availability and content of ionogenic groups in the polymer, but the nature of the polymer which determines the intensity of non-electrostatic interactions. What is referred to is mainly hydrogen bonds and hydrophobic interactions.

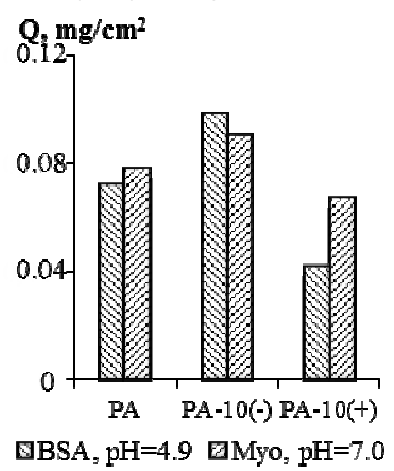

a $\mathrm{pH}=\mathrm{pI}$

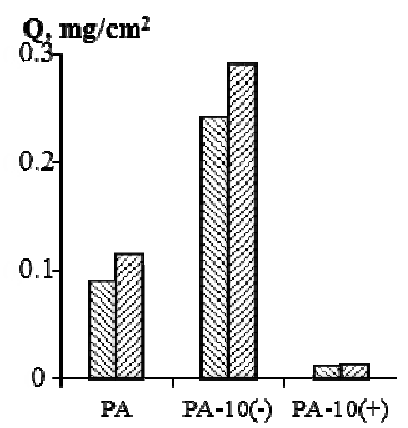

बBSA, $\mathrm{pH}=3.3$ खLys, $\mathrm{pH}=6.86$

b

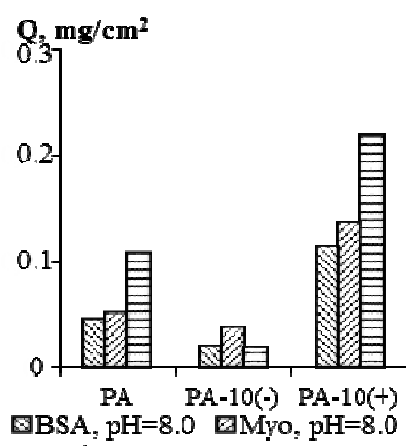

日Baci. $\mathrm{pH}=8.0$

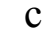

$\mathrm{pH}>\mathrm{pI}$

Fig. 2. The influence of protein solution $\mathrm{pH}$ on the maximum experimental adsorption capacity of polyamides membranes

The presence of hydrogen bonds between $-\mathrm{C}=\mathrm{O}$ and $\mathrm{H}-\mathrm{N}$ - groups of macromolecules of the polyamide and the protein in the systems being considered is indicated by the changes being observed in the area of carbonyl absorption (Amide I) in IR spectra of the polymer sample after bovine serum albumin sorption at $\mathrm{pH}=4.9$ (Fig.3). The lack of changes in the coordinates of maxima in the $\mathrm{SO}_{2}$ absorption area $\sim 1200 \mathrm{~cm}^{-1}$ should be pointed out, which confirms the non-ionic nature of the membrane/protein interactions.

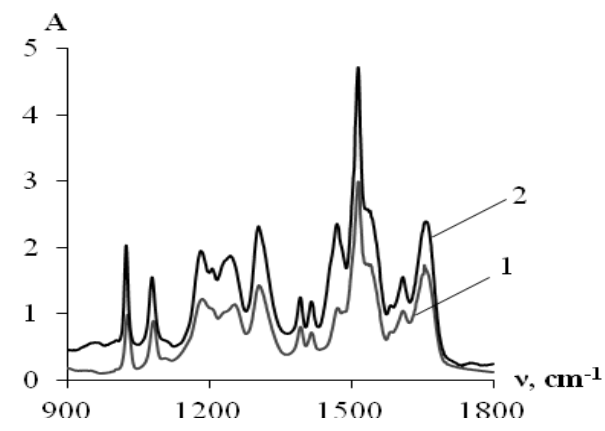

Fig. 3. IR spectra of poly-4,4-(2-sulfonate sodium)-diphenylaminoisophthalamide to (1) and after adsorption (2) BSA at $\mathrm{pH}=4.9$

The total contribution of hydrophobic forces to the adsorptive capacity of the investigated membranes can be assessed by comparing values of $\mathrm{Q}$ at $\mathrm{pH}$ equal to $\mathrm{pI}$ of the pro- 
tein for the PA membrane containing no specially introduced ionogenic groups to the results of investigations of commercial samples based on polyacrylonitrile (PAN) (IFOCh NANB) and polysulfone amide (UPM) (Vladimir) having similar mass exchange characteristics (Fig.4). The high level of values of $\mathrm{Q}$ obtained for poly-mphenyleneisophthalamide, in all likelihood, is due to hydrophobic membrane/protein interactions. It is known that for determination of the contribution of hydrophobic interactions to the adsorptive activity of materials of significant interest are temperature dependencies of adsorption, because the increase in temperature promotes hydrophobic interactions [34, 35]. The investigations of adsorption of lysozyme by synthesized membranes in the temperature range of 20 to $40^{\circ} \mathrm{C}$ revealed the increase in their adsorptive activity, manifested in the first place in the case of the PA sample [36].

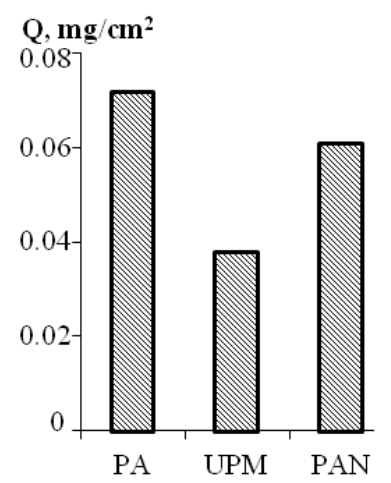

Fig. 4. Adsorption of BSA by various membranes at $\mathrm{pH}=4.9$

When above pI, proteins are charged negatively. In these conditions the dominance of repulsion forces between the likely charged surface of the PA-1(-), PA-3(-), PA-5(-) and PA-10(-) membranes and the protein macromolecules results in significant reduction of the adsorptive capacity of the membrane samples (Fig.1(b, c, d, f), Fig.2(c)).

In the case of the PA-10(+) membrane minimal adsorption is observed at $\mathrm{pH}<\mathrm{pI}$, maximal at $\mathrm{pH}>\mathrm{pI}($ Fig.1(g), Fig.2(b, c)). Results of mathematical processing of the experimental data are presented in Tables 4-7.

Table 4. Isotherms parameters for fit of proteins adsorption by membrane PA-1(-), PA$3(-)$, PA-5(-)

\begin{tabular}{|c|c|c|c|c|c|c|c|c|c|c|}
\hline \multirow[t]{2}{*}{$\mathrm{Mb}$} & \multirow[t]{2}{*}{ Protein } & \multicolumn{2}{|c|}{$\begin{array}{l}\text { Langmuir } \\
\text { isotherm }\end{array}$} & \multicolumn{2}{|c|}{$\begin{array}{c}\text { Freundlich } \\
\text { isotherm }\end{array}$} & \multicolumn{2}{|c|}{$\begin{array}{l}\text { Temkin } \\
\text { isotherm }\end{array}$} & \multicolumn{3}{|c|}{$\begin{array}{c}\text { Langmuir and } \\
\text { Freundlich isotherm }\end{array}$} \\
\hline & & $\mathrm{Q}$ & $\mathrm{b} \cdot 10^{3}$ & $K_{\mathrm{F}} \cdot 10^{3}$ & $1 / \mathrm{n}$ & $\mathrm{A}_{\mathrm{T}}$ & $\mathrm{b}_{\mathrm{T}} \cdot 10^{-4}$ & $\mathrm{Q}$ & $K_{L F} \cdot 10^{3}$ & $\mathrm{n}$ \\
\hline 1 & 2 & 3 & 4 & 5 & 6 & 7 & 8 & 9 & 10 & 11 \\
\hline \multirow{7}{*}{ PA1(-) } & $\begin{array}{c}\mathrm{BSA}, \\
\mathrm{pH}=3.3\end{array}$ & 0.164 & 0.81 & 0.21 & 0.88 & 0.010 & 7.51 & 0.255 & 0.41 & 1.01 \\
\hline & $\begin{array}{c}\mathrm{BSA}, \\
\mathrm{pH}=4.9\end{array}$ & 0.121 & 0.75 & 0.10 & 0.93 & 0.010 & 10.32 & 0.126 & 0.22 & 1.02 \\
\hline & $\begin{array}{c}\text { BSA, } \\
\mathrm{pH}=8.0\end{array}$ & 0.067 & 1.26 & 0.19 & 0.78 & 0.014 & 16.97 & 0.122 & 0.47 & 0.97 \\
\hline & $\begin{array}{c}\text { Lys, } \\
\mathrm{pH}=6.86\end{array}$ & 0.191 & 1.71 & 2.25 & 0.57 & 0.017 & 5.79 & 0.164 & 2.55 & 1.21 \\
\hline & $\begin{array}{c}\text { Myo, } \\
\mathrm{pH}=7.0\end{array}$ & 0.101 & 1.75 & 2.84 & 0.46 & 0.018 & 11.42 & 0.125 & 1.00 & 0.82 \\
\hline & $\begin{array}{c}\text { Myo, } \\
\mathrm{pH}=8.0\end{array}$ & 0.069 & 1.80 & 0.99 & 0.55 & 0.018 & 16.09 & 0.066 & 1.89 & 1.11 \\
\hline & $\begin{array}{c}\text { Baci, } \\
\mathrm{pH}=8.0\end{array}$ & 0.148 & 1.52 & 1.37 & 0.60 & 0.015 & 7.33 & 0.125 & 2.49 & 1.35 \\
\hline
\end{tabular}




\begin{tabular}{|c|c|c|c|c|c|c|c|c|c|c|}
\hline 1 & 2 & 3 & 4 & 5 & 6 & 7 & 8 & 9 & 10 & 11 \\
\hline \multirow{7}{*}{ PA3(-) } & $\begin{array}{c}\text { BSA, } \\
\mathrm{pH}=3.3\end{array}$ & 0.178 & 1.09 & 0.34 & 0.83 & 0.013 & 6.62 & 0.386 & 0.32 & 0.98 \\
\hline & $\begin{array}{c}\mathrm{BSA}, \\
\mathrm{pH}=4.9\end{array}$ & 0.122 & 0.81 & 0.12 & 0.91 & 0.011 & 10.07 & 0.299 & 0.25 & 1.01 \\
\hline & $\begin{array}{c}\text { BSA, } \\
\mathrm{pH}=8.0\end{array}$ & 0.048 & 1.36 & 0.19 & 0.73 & 0.015 & 24.53 & 0.081 & 0.51 & 0.91 \\
\hline & $\begin{array}{c}\text { Lys, } \\
\mathrm{pH}=6.86\end{array}$ & 0.224 & 1.95 & 3.00 & 0.56 & 0.019 & 4.93 & 0.185 & 3.36 & 1.48 \\
\hline & $\begin{array}{c}\text { Myo, } \\
\mathrm{pH}=7.0\end{array}$ & 0.112 & 1.47 & 1.48 & 0.54 & 0.016 & 10.45 & 0.183 & 0.41 & 0.75 \\
\hline & $\begin{array}{c}\text { Myo, } \\
\mathrm{pH}=8.0\end{array}$ & 0.069 & 1.47 & 0.82 & 0.56 & 0.015 & 16.52 & 0.081 & 0.96 & 0.87 \\
\hline & $\begin{array}{c}\text { Baci, } \\
\mathrm{pH}=8.0\end{array}$ & 0.130 & 2.18 & 2.33 & 0.52 & 0.019 & 8.26 & 0.111 & 3.44 & 1.42 \\
\hline \multirow{7}{*}{ PA5(-) } & $\begin{array}{c}\text { BSA, } \\
\mathrm{pH}=3.3\end{array}$ & 0.213 & 1.20 & 0.47 & 0.82 & 0.014 & 5.52 & 0.271 & 0.75 & 1.06 \\
\hline & $\begin{array}{c}\mathrm{BSA}, \\
\mathrm{pH}=4.9\end{array}$ & 0.124 & 0.84 & 0.17 & 0.87 & 0.012 & 9.72 & 0.260 & 0.33 & 1.01 \\
\hline & $\begin{array}{c}\text { BSA, } \\
\mathrm{pH}=8.0\end{array}$ & 0.041 & 1.57 & 0.24 & 0.68 & 0.016 & 27.53 & 0.070 & 0.55 & 0.89 \\
\hline & $\begin{array}{c}\text { Lys, } \\
\mathrm{pH}=6.86\end{array}$ & 0.254 & 1.91 & 3.78 & 0.54 & 0.019 & 4.47 & 0.221 & 2.75 & 1.25 \\
\hline & $\begin{array}{c}\text { Муо, } \\
\mathrm{pH}=7.0\end{array}$ & 0.114 & 1.56 & 1.38 & 0.56 & 0.016 & 10.07 & 0.107 & 1.88 & 1.14 \\
\hline & $\begin{array}{c}\text { Myo, } \\
\mathrm{pH}=8.0\end{array}$ & 0.059 & 1.45 & 0.82 & 0,53 & 0.016 & 19.98 & 0.079 & 0.70 & 0.79 \\
\hline & $\begin{array}{c}\text { Baci, } \\
\mathrm{pH}=8.0\end{array}$ & 0.130 & 1.66 & 1.37 & 0.59 & 0.015 & 8.34 & 0.108 & 2.62 & 1.31 \\
\hline
\end{tabular}

Table 5. Isotherms parameters for fit of proteins adsorption by membrane PA, PA-10(-), PA-10(+)

\begin{tabular}{|c|c|c|c|c|c|c|c|c|c|c|}
\hline \multirow{2}{*}{$\mathrm{Mb}$} & \multirow{2}{*}{ Protein } & \multicolumn{2}{|c|}{$\begin{array}{l}\text { Langmuir } \\
\text { isotherm }\end{array}$} & \multicolumn{2}{|c|}{$\begin{array}{l}\text { Freundlich } \\
\text { isotherm }\end{array}$} & \multicolumn{2}{|c|}{$\begin{array}{c}\text { Temkin } \\
\text { isotherm }\end{array}$} & \multicolumn{3}{|c|}{$\begin{array}{c}\text { Langmuir and } \\
\text { Freundlich isotherm }\end{array}$} \\
\hline & & $\mathrm{Q}$ & $\mathrm{b} \cdot 10^{3}$ & $\begin{array}{c}\mathrm{K}_{\mathrm{F}} \\
\cdot 10^{3}\end{array}$ & $1 / \mathrm{n}$ & $\mathrm{A}_{\mathrm{T}}$ & $\mathrm{b}_{\mathrm{T}} \cdot 10^{-4}$ & Q & $\mathrm{K}_{\mathrm{LF}} \cdot 10^{3}$ & $\mathrm{n}$ \\
\hline 1 & 2 & 3 & 4 & 5 & 6 & 7 & 8 & 9 & 10 & 11 \\
\hline \multirow{7}{*}{ PA } & $\begin{array}{c}\mathrm{BSA}, \\
\mathrm{pH}=3.3\end{array}$ & 0.122 & 1.53 & 1.08 & 0.61 & 0.015 & 9.04 & 0.097 & 2.85 & 1.46 \\
\hline & $\begin{array}{c}\mathrm{BSA} \\
\mathrm{pH}=4.9\end{array}$ & 0.097 & 1.40 & 1.01 & 0.57 & 0.015 & 11.85 & 0.091 & 1.77 & 1.06 \\
\hline & $\begin{array}{c}\text { BSA, } \\
\mathrm{pH}=8.0\end{array}$ & 0.075 & 0.77 & 0.21 & 0.72 & 0.011 & 17.57 & 0.056 & 1.51 & 1.27 \\
\hline & $\begin{array}{c}\text { Lys, } \\
\mathrm{pH}=6.86\end{array}$ & 0.150 & 1.78 & 1.84 & 0.57 & 0.017 & 7.33 & 0.133 & 2.34 & 1.19 \\
\hline & $\begin{array}{c}\text { Myo, } \\
\mathrm{pH}=7.0\end{array}$ & 0.103 & 1.47 & 1.28 & 0.55 & 0.015 & 11.21 & 0.117 & 1.10 & 0.89 \\
\hline & $\begin{array}{c}\text { Myo, } \\
\mathrm{pH}=8.0\end{array}$ & 0.065 & 1.79 & 1.12 & 0.52 & 0.018 & 17.45 & 0.076 & 1.15 & 0.86 \\
\hline & $\begin{array}{c}\text { Baci, } \\
\mathrm{pH}=8.0\end{array}$ & 0.145 & 1.39 & 1.36 & 0.59 & 0.015 & 7.94 & 0.128 & 1.99 & 1.19 \\
\hline
\end{tabular}




\begin{tabular}{|c|c|c|c|c|c|c|c|c|c|c|}
\hline 1 & 2 & 3 & 4 & 5 & 6 & 7 & 8 & 9 & 10 & 11 \\
\hline \multirow{7}{*}{ PA 10(-) } & $\begin{array}{c}\text { BSA, } \\
\mathrm{pH}=3.3\end{array}$ & 0.338 & 1.31 & 0.81 & 0.81 & 0.016 & 3.48 & 0.490 & 0.62 & 1.04 \\
\hline & $\begin{array}{c}\mathrm{BSA}, \\
\mathrm{pH}=4.9\end{array}$ & 0.134 & 1.11 & 0.24 & 0.84 & 0.013 & 8.60 & 0.257 & 0.42 & 1.01 \\
\hline & $\begin{array}{c}\mathrm{BSA}, \\
\mathrm{pH}=8.0\end{array}$ & 0.028 & 1.01 & 0.05 & 0.82 & 0.012 & 42.72 & 0.042 & 0.55 & 1.02 \\
\hline & $\begin{array}{c}\text { Lys, } \\
\mathrm{pH}=6.86\end{array}$ & 0.378 & 1.99 & 4.74 & 0.57 & 0.019 & 2.87 & 0.310 & 3.19 & 1.33 \\
\hline & $\begin{array}{c}\text { Myo, } \\
\mathrm{pH}=7.0\end{array}$ & 0.119 & 1.53 & 1.41 & 0.56 & 0.016 & 9.64 & 0.118 & 1.56 & 1.04 \\
\hline & $\begin{array}{c}\text { Myo, } \\
\mathrm{pH}=8.0\end{array}$ & 0.056 & 0.92 & 0.28 & 0.65 & 0.012 & 22.52 & 0.051 & 1.24 & 1.08 \\
\hline & $\begin{array}{c}\text { Baci, } \\
\mathrm{pH}=8.0\end{array}$ & 0.127 & 1.19 & 0.74 & 0.65 & 0.013 & 8.98 & 0.102 & 2.03 & 1.27 \\
\hline \multirow{7}{*}{ PA $10(+)$} & $\begin{array}{c}\text { BSA, } \\
\mathrm{pH}=3.3\end{array}$ & 0.017 & 1.20 & 0.10 & 0.65 & 0.014 & 66.96 & 0.013 & 2.28 & 1.43 \\
\hline & $\begin{array}{c}\mathrm{BSA}, \\
\mathrm{pH}=4.9\end{array}$ & 0.057 & 1.59 & 0.57 & 0.59 & 0.016 & 19.51 & 0.050 & 2.03 & 1.20 \\
\hline & $\begin{array}{c}\text { BSA, } \\
\mathrm{pH}=8.0\end{array}$ & 0.163 & 1.15 & 0.89 & 0.66 & 0.013 & 7.18 & 0.125 & 2.33 & 1.41 \\
\hline & $\begin{array}{c}\text { Lys, } \\
\mathrm{pH}=6.86\end{array}$ & 0.017 & 2.99 & 2.42 & 0.24 & 0.028 & 63.53 & 0.014 & 5.05 & 2.77 \\
\hline & $\begin{array}{c}\text { Myo, } \\
\mathrm{pH}=7.0\end{array}$ & 0.086 & 1.56 & 1.47 & 0.51 & 0.017 & 13.76 & 0.170 & 0.26 & 0.66 \\
\hline & $\begin{array}{c}\text { Myo, } \\
\mathrm{pH}=8.0\end{array}$ & 0.215 & 0.89 & 0.78 & 0.70 & 0.011 & 5.80 & 0.173 & 1.47 & 1.19 \\
\hline & $\begin{array}{c}\text { Baci, } \\
\mathrm{pH}=8.0\end{array}$ & 0.299 & 1.49 & 2.55 & 0.61 & 0.015 & 3.70 & 0.247 & 2.35 & 1.30 \\
\hline
\end{tabular}

Table 6. Regression parameters for fit of proteins adsorption by membrane PA-1(-), PA-3(-), PA-5(-)

\begin{tabular}{|c|c|c|c|c|c|c|c|c|c|}
\hline \multirow[t]{2}{*}{$\mathrm{Mb}$} & \multirow{2}{*}{ Protein } & \multicolumn{2}{|c|}{$\begin{array}{l}\text { Langmuir } \\
\text { isotherm }\end{array}$} & \multicolumn{2}{|c|}{$\begin{array}{l}\text { Freundlich } \\
\text { isotherm }\end{array}$} & \multicolumn{2}{|c|}{$\begin{array}{l}\text { Temkin } \\
\text { isotherm }\end{array}$} & \multicolumn{2}{|c|}{$\begin{array}{l}\text { Langmuir and } \\
\text { Freundlich } \\
\text { isotherm }\end{array}$} \\
\hline & & $\mathrm{R}^{2}$ & $\begin{array}{l}\text { SSE, } \\
\cdot 10^{5}\end{array}$ & $\mathrm{R}^{2}$ & $\begin{array}{l}\text { SSE, } \\
\cdot 10^{4}\end{array}$ & $\mathrm{R}^{2}$ & $\begin{array}{l}\text { SSE, } \\
\cdot 10^{5}\end{array}$ & $\mathrm{R}^{2}$ & $\begin{array}{l}\text { SSE, } \\
\cdot 10^{6}\end{array}$ \\
\hline 1 & 2 & 3 & 4 & 5 & 6 & 7 & 8 & 9 & 10 \\
\hline \multirow{7}{*}{ PA1(-) } & $\begin{array}{c}\text { BSA, } \\
\mathrm{pH}=3.3\end{array}$ & 0.982 & 8.09 & 0.861 & 17.9 & 0.961 & 25.12 & 0.999 & 9.04 \\
\hline & $\begin{array}{c}\text { BSA, } \\
\mathrm{pH}=4.9\end{array}$ & 0.966 & 8.80 & 0.852 & 8.67 & 0.948 & 17.51 & 0.992 & 23.81 \\
\hline & $\begin{array}{c}\text { BSA, } \\
\mathrm{pH}=8.0\end{array}$ & 0.982 & 1.83 & 0.817 & 22.51 & 0.968 & 4.18 & 0.999 & 1.45 \\
\hline & $\begin{array}{c}\text { Lys, } \\
\mathrm{pH}=6.86\end{array}$ & 0.991 & 8.28 & 0.899 & 9.40 & 0.987 & 11.92 & 0.994 & 5.36 \\
\hline & $\begin{array}{c}\text { Myo, } \\
\mathrm{pH}=7.0\end{array}$ & 0.992 & 1.93 & 0.864 & 3.12 & 0.993 & 1.69 & 0.997 & 6.18 \\
\hline & $\begin{array}{c}\text { Myo, } \\
\mathrm{pH}=8.0\end{array}$ & 0.984 & 1.82 & 0.868 & 1.53 & 0.989 & 1.25 & 0.975 & 28.41 \\
\hline & $\begin{array}{c}\text { Baci, } \\
\mathrm{pH}=8.0\end{array}$ & 0.986 & 8.04 & 0.880 & 6.67 & 0.993 & 3.94 & 0.998 & 2.13 \\
\hline
\end{tabular}




\begin{tabular}{|c|c|c|c|c|c|c|c|c|c|}
\hline 1 & 2 & 3 & 4 & 5 & 6 & 7 & 8 & 9 & 10 \\
\hline \multirow{7}{*}{ PA3(-) } & $\begin{array}{c}\text { BSA, } \\
\mathrm{pH}=3.3\end{array}$ & 0.979 & 114.40 & 0.824 & 16.3 & 0.962 & 33.31 & 0.992 & 6.52 \\
\hline & $\begin{array}{c}\mathrm{BSA}, \\
\mathrm{pH}=4.9\end{array}$ & 0.967 & 9.21 & 0.842 & 8.32 & 0.949 & 18.31 & 0.998 & 8.70 \\
\hline & $\begin{array}{c}\mathrm{BSA}, \\
\mathrm{pH}=8.0\end{array}$ & 0.972 & 1.42 & 0.795 & 8.78 & 0.966 & 2.17 & 0.981 & 11.82 \\
\hline & $\begin{array}{c}\text { Lys, } \\
\mathrm{pH}=6.86\end{array}$ & 0.980 & 25.91 & 0.852 & 19.52 & 0.983 & 23.10 & 0.988 & 16.22 \\
\hline & $\begin{array}{c}\text { Муо, } \\
\mathrm{pH}=7.0\end{array}$ & 0.980 & 3.67 & 0.983 & 0.48 & 0.982 & 5.02 & 0.990 & 26.8 \\
\hline & $\begin{array}{c}\text { Мyo, } \\
\mathrm{pH}=8.0\end{array}$ & 0.998 & 0.21 & 0.961 & 0.43 & 0.992 & 0.93 & 0.998 & 2.62 \\
\hline & $\begin{array}{c}\text { Baci, } \\
\mathrm{pH}=8.0\end{array}$ & 0.979 & 9.60 & 0.846 & 6.91 & 0.972 & 12.81 & 0.988 & 55.83 \\
\hline \multirow{7}{*}{ PA5(-) } & $\begin{array}{c}\text { BSA, } \\
\mathrm{pH}=3.3\end{array}$ & 0.984 & 16.52 & 0.838 & 29.21 & 0.977 & 30.52 & 0.986 & 49.31 \\
\hline & $\begin{array}{c}\mathrm{BSA}, \\
\mathrm{pH}=4.9\end{array}$ & 0.977 & 6.55 & 0.844 & 18.82 & 0.960 & 15.61 & 0.999 & 2.11 \\
\hline & $\begin{array}{c}\text { BSA, } \\
\mathrm{pH}=8.0\end{array}$ & 0.991 & 0.36 & 0.767 & 4.90 & 0.977 & 1.16 & 0.996 & 1.94 \\
\hline & $\begin{array}{c}\text { Lys, } \\
\mathrm{pH}=6.86\end{array}$ & 0.993 & 12.10 & 0.920 & 12.70 & 0.998 & 3.80 & 0.998 & 2.91 \\
\hline & $\begin{array}{c}\text { Myo, } \\
\mathrm{pH}=7.0\end{array}$ & 0.811 & 11.42 & 0.938 & 1.82 & 0.997 & 0.95 & 0.984 & 46.50 \\
\hline & $\begin{array}{c}\text { Муо, } \\
\mathrm{pH}=8.0\end{array}$ & 0.985 & 1.11 & 0.992 & 0.06 & 0.979 & 1.57 & 0.994 & 4.27 \\
\hline & $\begin{array}{c}\text { Baci, } \\
\mathrm{pH}=8.0\end{array}$ & 0.979 & 9.03 & 0.829 & 7.48 & 0.977 & 10.10 & 0.993 & 13.92 \\
\hline
\end{tabular}

Table 7. Regression parameters for fit of proteins adsorption by membrane PA, PA-10(-), PA-10(+)

\begin{tabular}{|c|c|c|c|c|c|c|c|c|c|}
\hline \multirow[t]{2}{*}{$\mathrm{Mb}$} & \multirow[t]{2}{*}{ Protein } & \multicolumn{2}{|c|}{$\begin{array}{l}\text { Langmuir } \\
\text { isotherm }\end{array}$} & \multicolumn{2}{|c|}{$\begin{array}{l}\text { Freundlich } \\
\text { isotherm }\end{array}$} & \multicolumn{2}{|c|}{$\begin{array}{l}\text { Temkin } \\
\text { isotherm }\end{array}$} & \multicolumn{2}{|c|}{$\begin{array}{l}\text { Langmuir and } \\
\text { Freundlich } \\
\text { isotherm }\end{array}$} \\
\hline & & $\mathrm{R}^{2}$ & $\begin{array}{l}\text { SSE, } \\
\cdot 10^{5}\end{array}$ & $\mathrm{R}^{2}$ & $\begin{array}{l}\mathrm{SSE}, \\
\cdot 10^{4}\end{array}$ & $\mathrm{R}^{2}$ & $\begin{array}{l}\mathrm{SSE}, \\
\cdot 10^{5}\end{array}$ & $\mathrm{R}^{2}$ & $\begin{array}{l}\text { SSE, } \\
\cdot 10^{6}\end{array}$ \\
\hline \multirow{7}{*}{ PA } & $\begin{array}{c}\mathrm{BSA}, \\
\mathrm{pH}=3.3\end{array}$ & 0.978 & 8.39 & 0.832 & 6.27 & 0.982 & 6.66 & 0.991 & 32.51 \\
\hline & $\begin{array}{c}\mathrm{BSA}, \\
\mathrm{pH}=4.9\end{array}$ & 0.994 & 1.21 & 0.959 & 0.89 & 0.988 & 2.60 & 0.988 & 24.32 \\
\hline & $\begin{array}{c}\text { BSA, } \\
\mathrm{pH}=8.0\end{array}$ & 0.994 & 0.61 & 0.943 & 0.55 & 0.986 & 1.27 & 0.989 & 10.31 \\
\hline & $\begin{array}{c}\text { Lys, } \\
\mathrm{pH}=6.86\end{array}$ & 0.993 & 4.17 & 0.877 & 7.10 & 0.992 & 4.52 & 0.995 & 26.03 \\
\hline & $\begin{array}{c}\text { Myo, } \\
\mathrm{pH}=7.0\end{array}$ & 0.997 & 0.79 & 0.978 & 0.53 & 0.989 & 2.58 & 0.998 & 4.51 \\
\hline & $\begin{array}{c}\text { Myo, } \\
\mathrm{pH}=8.0\end{array}$ & 0.996 & 0.38 & 0.939 & 0.60 & 0.994 & 0.61 & 0.993 & 6.64 \\
\hline & $\begin{array}{c}\text { Baci, } \\
\mathrm{pH}=8.0\end{array}$ & 0.994 & 2.79 & 0.937 & 2.90 & 0.996 & 1.78 & 0.991 & 40.32 \\
\hline
\end{tabular}




\begin{tabular}{|c|c|c|c|c|c|c|c|c|c|}
\hline 1 & 2 & 3 & 4 & 5 & 6 & 7 & 8 & 9 & 10 \\
\hline \multirow{7}{*}{ PA 10(-) } & $\begin{array}{c}\text { BSA, } \\
\mathrm{pH}=3.3\end{array}$ & 0.983 & 44.83 & 0.834 & 72.81 & 0.969 & 11.10 & 0.988 & 41.71 \\
\hline & $\begin{array}{c}\mathrm{BSA}, \\
\mathrm{pH}=4.9\end{array}$ & 0.981 & 9.70 & 0.832 & 2.20 & 0.956 & 22.23 & 0.999 & 6.16 \\
\hline & $\begin{array}{c}\mathrm{BSA}, \\
\mathrm{pH}=8.0\end{array}$ & 0.984 & 0.25 & 0.808 & 3.11 & 0.972 & 0.57 & 0.995 & 1.02 \\
\hline & $\begin{array}{c}\text { Lys, } \\
\mathrm{pH}=6.86\end{array}$ & 0.976 & 96.71 & 0.840 & 64.81 & 0.973 & 11.21 & 0.994 & 22.42 \\
\hline & $\begin{array}{c}\text { Myo, } \\
\mathrm{pH}=7.0\end{array}$ & 0.997 & 1.06 & 0.953 & 1.51 & 0.998 & 6.35 & 0.996 & 14.13 \\
\hline & $\begin{array}{c}\text { Myo, } \\
\mathrm{pH}=8.0\end{array}$ & 0.983 & 1.03 & 0.975 & 0.15 & 0.964 & 2.16 & 0.991 & 9.73 \\
\hline & $\begin{array}{c}\text { Baci, } \\
\mathrm{pH}=8.0\end{array}$ & 0.983 & 6.47 & 0.885 & 4.31 & 0.985 & 5.80 & 0.995 & 18.71 \\
\hline \multirow{7}{*}{$\begin{array}{c}\text { PA } \\
10(+)\end{array}$} & $\begin{array}{c}\mathrm{BSA}, \\
\mathrm{pH}=3.3\end{array}$ & 0.985 & 0.10 & 0.871 & 0.08 & 0.997 & 0.02 & 0.992 & 0.55 \\
\hline & $\begin{array}{c}\text { BSA, } \\
\mathrm{pH}=4.9\end{array}$ & 0.988 & 0.95 & 0.868 & 1.03 & 0.989 & 0.89 & 0.989 & 8.45 \\
\hline & $\begin{array}{c}\text { BSA, } \\
\mathrm{pH}=8.0\end{array}$ & 0.983 & 9.91 & 0.877 & 7.20 & 0.990 & 5.80 & 0.984 & 19.21 \\
\hline & $\begin{array}{c}\text { Lys, } \\
\mathrm{pH}=6.86\end{array}$ & 0.858 & 1.23 & 0.661 & 0.29 & 0.838 & 1.41 & 0.999 & 1.86 \\
\hline & $\begin{array}{c}\text { Myo, } \\
\mathrm{pH}=7.0\end{array}$ & 0.979 & 3.39 & 0.988 & 0.19 & 0.979 & 3.36 & 0.998 & 3.15 \\
\hline & $\begin{array}{c}\text { Myo, } \\
\mathrm{pH}=8.0\end{array}$ & 0.996 & 3.69 & 0.918 & 7.31 & 0.994 & 5.69 & 0.999 & 10.11 \\
\hline & $\begin{array}{c}\text { Baci, } \\
\mathrm{pH}=8.0\end{array}$ & 0.990 & 31.10 & 0.868 & 2.93 & 0.989 & 2.51 & 0.998 & 40.23 \\
\hline
\end{tabular}

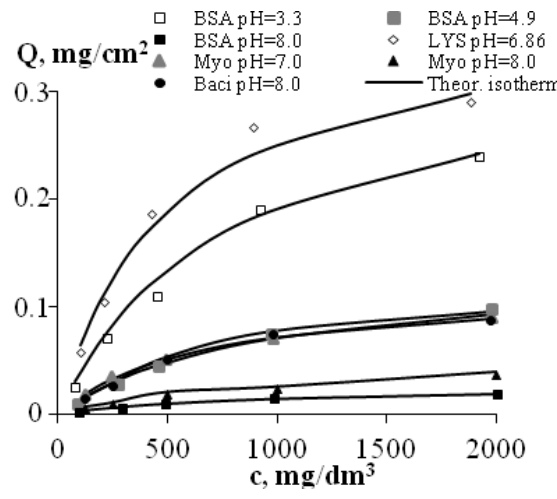

a

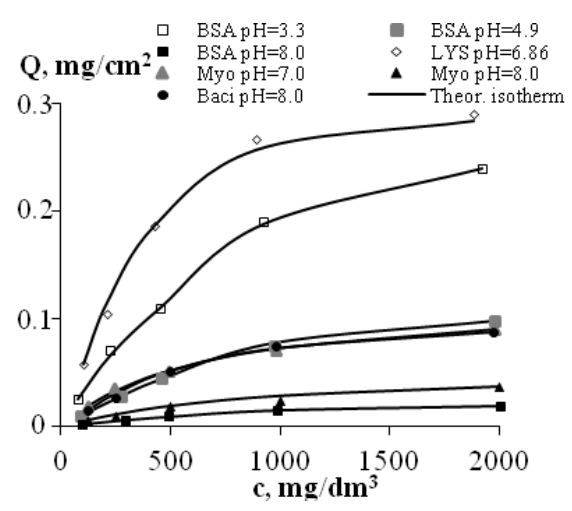

b

Fig. 5. Langmuir (a), Langmuir and Freundlich (b) isotherm of protein adsorption by membrane PA-10(-); $\mathrm{T}=20^{\circ} \mathrm{C}$

The obtained values of $\mathrm{R}^{2}$ and SSE as well as the character of dependencies shown in Fig.5 indicate the advisability of using the models by Langmuir and LangmuirFreundlich for the description of the conducted experiments.

\section{Conclusion}

The comparative analysis of adsorption of several proteins by a number of ultrafiltration membranes based on aromatic poly- and copolyamides made it possible to deter- 
mine the contribution of forces of electrostatic and non-electrostatic nature to the mechanism of adsorption.

It has been shown that availability of aromatic fragments and amide groups in the macromolecular chain of polyamides makes a significant contribution to hydrophobic interactions and hydrogen bonds implemented in the membrane/protein system, which, in its turn, determines a high level of adsorptive activity of membranes, irrespective of availability and nature of ionogenic groups. However, introduction of ionogenic groups into the membrane-forming composition results in domination of electrostatic interactions in the membrane/protein adsorption mechanism. This is why the control tools of electrostatic interactions (concentration and nature of ionogenic groups in the copolymer or in polymer composition and $\mathrm{pH}$ of the protein solution) are the tools for controlling adsorptive properties of synthesized membranes.

The understanding of basic regularities of adsorptive processes in the investigated systems opens the way of producing membranes having controlled mass exchange characteristics implemented in filtration of both solutions of individual model proteins and real protein mixtures.

\section{References}

1. Volkov V.V., Mchedlishvili B.V., Roldugin V.I., Ivanchev S.S., Rossijskie Nanotekhnol., 2008, Vol. 3, No 11-12, pp. 67-100.

2. Comprehensive membrane science and engineering. Ed. by Drioli E., Giorno L., Amsterdam, Elsevier, 2010, pt. 2, 490 p.

3. Membrane separations chemical, pharmaceutical, food, and biotechnological applications: handbook. Ed. by Pabby A.K., Rizvi S.H., Sastre A.M., New-York, CRC Press, 2015, 845 p.

4. Cherkasov A.N., J. Membr. Sci., 1990, Vol. 50, pp. 109-130.

5. Zhou Y., Wang Zh., Zhang Q., Xi X. et al., Desalination, 2012, Vol. 307, pp. 61-67.

6. Ho C., Zydney A., J. Ind. Eng. Chem. Research, 2001, Vol. 40, pp. 1412-1421.

7. Peeva P.D., Palupi A.E., Ulbricht M., J. Separ. Purif. Technol., 2011, Vol. 81, pp. 124-133.

8. Mukai Y., Iritani E., Murase T., J. Membr. Sci., 1997, Vol. 137, pp. 271-275.

9. Ishiguro R., Yokoyama Y., Maeda H., Shimamura A. et al., J. Col. Interface Sci., 2005, Vol. 290, pp. 91-101.

10.Hernandes A., Huisman I., Pradanos P., J. Membr. Sci., 2000, Vol. 179, pp. 79-90.

11.Jones K.L., O’Melia C.R., J. Membr. Sci., 2000, Vol. 165, pp. 31-46.

12.Jara F.L., Sanchez C.C., Patino J.M.R., Pilosof A.M.R., Food Hydrocoll., 2014, Vol. 35, pp. 189-197.

13. Gao Z., Liu T., Miao R., J. Environ. Sci. Technol., 2015, Vol. 13, pp. 1-26.
14.Ramachandhran V., Ghosh A.K., Prabhakar S., Tewari P.K., Separ. Sci. Technol., 2009, Vol. 44, pp. 599-614.

15.Hurwitz G., Guillen G.R., Hoek E.M.V., J. Membr. Sci., 2010, Vol. 349, pp. 349-357.

16.Cherkasov A.N., Membrany, 2002, Vol. 14, pp. 3-17.

17. Berezkin V.V., Kiseleva O.A., Nechaev A.N., Sobolev V.D. et al., Kolloid. Zhurnal, 1994, Vol. 56, No 3, pp. 319-325.

18. Cherkasov A.N., Membr. Struct. Separ. Sci. Technol., 2005, Vol. 40, No 14, pp. 27752801.

19. Tristram G.R., Proteins. Ed. by H. Neurath, K. Bailey, New-York, Acad. Press, 1953, Vol. 1, 549 p.

20. White A., Handler Ph., Smit E., Principles of biochemistry, New-York, Acad. Press, 1978, Vol. 1, 731p.

21.Lehninger A.L., Biochemistry, New-York, Worth Publ., 1972, Vol. 1, 368 p.

22.Phillips D.C., Lysozyme, New-York, Acad. Press, 1974, $350 \mathrm{p}$.

23.Jakubke H.-D., Jeschkeit H., Aminosuren, Peptide, Proteine. Berlin, Akad. Verlag, $1982,457 \mathrm{p}$.

24. Tenford C., Physical chemistry of macromolecules. New-York, Wiley, 1961, 772 p.

25.Volkenshteyn M.V., Biofizika, M., Nauka, 1988, 592 p.

26.Dabrowski A., Adv. Colloid Interface Sci., 2001, Vol. 93, pp. 135-224. 
27.Foo K.Y., Hameed B.H., Chem. Eng. J., 2010, Vol. 156, pp. 2-10.

28. Quiroga E., Ramirez-Pastor A.J., Chem. Phys. Letters, 2013, Vol. 556, pp. 330-335.

29.Salgin S., Takac S., Ozdamar T., J. Membr. Sci., 2006, Vol. 278, pp. 251-260.

30. Li W., Li S., J. Colloid Surfaces, 2007, Vol. 295, pp. 159-164.

31.Molek J., Ruanjaikaen K., Zydney A., $J$. Membr. Sci., 2010, Vol. 353, pp. 60-69.

32.Hartvig R.A., Van de Weert M., Ostergaard J., Jorgensen L. et al., J. Langmuir, 2011, Vol. 27, pp. 2634-2643.

Смирнова Наталья Николаевна - профессор кафедры химии, д.х.н., Владимирский государственный университет им. А.Г. и Н.Г. Столетовых, Владимир

Небукина Ирина Александровна - аспирантка кафедры химии, Владимирский государственный университет им. А.Г. и Н.Г. Столетовых, Владимир.
33. Norde W., Luklema J., J. Biomater. Sci. Polym., Ed. 2, 1991, pp. 183-202.

34.Vasheghani F., Rajabi F.H., Ahmadi M.H., Nouhi S., Polym. Bull., 2006, Vol. 56, pp. 395-404.

35.Bonomo R.C.F., Minim L.A., Coimbra J.S.R., Fontan R.C.. et al., J. Chromatogr., 2006, Vol. 844, pp. 6-14.

36. Smirnova N.N., Nebukina I.A., Sorbtsionnye i khromatograficheskie protsessy, 2014, Vol. 14, pp. 150-158.

Smirnova Natalya N. - prof., grand Ph.D (chemistry), department of chemistry, Vladimir State University named after A.G. and N.G. Stoletovs, Vladimir, e-mail: smirnovann@list.ru

Nebukina Irina A. - post graduate of the chair of chemistry department, Vladimir State University named after A.G. and N.G. Stoletovs, Vladimir 